\title{
ER01A Gene
}

National Cancer Institute

\section{Source}

National Cancer Institute. ERO1A Gene. NCI Thesaurus. Code C114625.

This gene plays a role in both protein oxidation and disulfide bond formation. 